\title{
ПРЕДВАРИТЕЛЬНОЕ РЕНТГЕНОСТРУКТУРНОЕ ИССЛЕДОВАНИЕ НЕКОТОРЫХ ЗАМЕЩЕННЫХ $\varepsilon$-КАПРОЛАКТАМОВ
}

H. OJA, R. MJASNIKOVA, P. CHRISTJANSON, MONINGATE ASENDATUD $g$-KAPROLAKTAAMIDE KRISTALLOGRAAFILISED PARAMEETRID

H. OJA, R. MYASNIKOVA, P. CHRISTJANSON. CHRISTALLOGRAPHIC PARAMETERS OF SOME SUBSTITUTED $\varepsilon$-CAPROLACTAMS

(Представил О. Эйзен)

Одной из побочных реакций, сопутствующих синтезу фенолформальдегидных клеевых смол на основе сланцевых двухатомных фенолов в присутствии $\mathrm{N}$-оксиметил-в-капролактама (МКЛ), является реакция амидометилирования фенолов, в результате которой образуются (в зависимости от условий реакции) моно-, ди- или тризамещенные резорцины с амидометильными группами (см. ['] и содержащиеся там ссылки). Изучение реакции резорцинов с МКЛ представляет и самостоятельный интерес как с точки зрения применения лактамов в реакции Манниха, так и изучения внутримолекулярной водородной связи в молекулах продуктов этой реакции.

Молекулярная структура двух продуктов реакции амидометилиро-

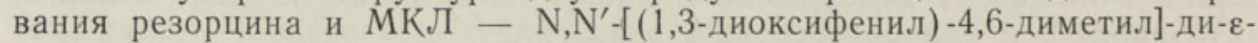
капролактама (1) и $\mathrm{N}, \mathrm{N}^{\prime}, \mathrm{N}^{\prime \prime}-[(1,3$-диоксифенил) -2,4,6-триметил]-три$\boldsymbol{\varepsilon}$-капролактама $(2)$ - была установлена методами физико-химического анализа, ${ }^{1} \mathrm{H},{ }^{13} \mathrm{C}$ ЯМР- и ИК-спектроскопии $\left[{ }^{2,3}\right]$. В этих же работах было показано, что в разбавленных растворах для молекул названных веществ характерно образование хелатного мостика за счет внутримолекулярной водородной связи (Н-связи) $\mathrm{C}=\mathrm{O}$ (лактам) ... H-O (резорцин). Данные ИК-спектроскопии свидетельствуют о том, что в твердой фазе соединений (1) и (2) присутствуют, только Н-связи $\mathrm{C}=\mathrm{O} \ldots \mathrm{H}-\mathrm{O}\left[{ }^{2,3}\right]$, однако по ИК-спектрам нельзя отнести их однозначно к внутри- или межмолекулярным. Для установления характера Н-связей в твердой фазе рассматриваемых веществ, в общей программе исследования продуктов реакции амидометилирования фенолов, нами проведено предварительное рентгеноструктурное исследование (1) и (2) с целью выбора объекта для полной расшифровки структуры. Приводим рентгенографические данные этих соединений: 


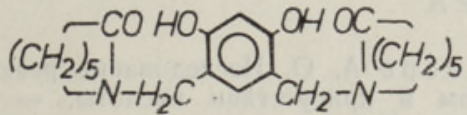

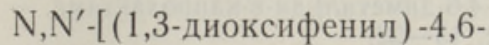
диметил]-ди- $\varepsilon$-капролактам $a=7,54 \AA$

$b=13,96$

$c=17,57$

$\alpha=\beta=\gamma=90^{\circ}$

дифракционный класс:

mmm P $2_{1} 2_{1} 2_{1}$

пространственная группа:

$P 2{ }_{1} 2_{1} 2_{1}$

$V_{\text {яч }}=1849,4 \AA^{3}$

$V_{\text {мол }}=330 \AA^{3}$

$Z=4$

$k=0,71$

$d_{\text {рентг }}=1,294$ г/ $\mathrm{CM}^{3}$

$d_{4 \text { нам }}^{20}=1,285$ г $/ \mathrm{CM}^{3}$
(1)

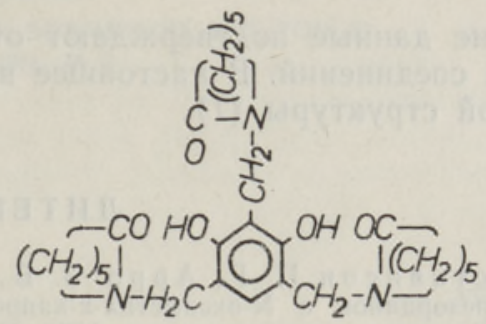

где $V_{\text {яч }}$ - объем ячейки, $V_{\text {мол }}-$ собственный объем молекулы, при подсчете которого применялись межмолекулярные радиусы атомов $R_{C}=1,80 ; R_{O}=1,52 ; R_{N}=1,57 ; R_{H}=1,17 \AA\left[{ }^{4}\right] ; Z$ - число молекул в элементарной ячейке; $k-$ коэффициент упаковки $\left(k=Z \cdot V_{\text {мол }} / V_{\text {яч }}\right)$; $d_{\text {рентг }}$ - рентгеновская плотность; $d_{4 \text { изм }}^{20}-$ измеренная плотность.

Краткое описание эксперимента. Монокристаллы для рентгеновского исследования были получены выкристаллизацией из раствора соединения (1) в ацетоне и (2) в пиридине. Полученные таким способом монокристаллы этих соединений прозрачны, бесцветны, с нечетко выраженной огранкой, имеют форму призмы, вытянутой в случае соединения (1) в направлении кристаллографической оси [001], а в случае соединения (2) - вдоль [110]. Периоды решетки определены по рентгенограммам качания, снятым в камере РКОП (Сu-излучение). Относительная погрешность определения периодов составляет $0,5-1,0 \%$, ошибка определения моноклинного угла - $\pm 0,5^{\circ}$. Выбранные элеменгарные ячейки были проверены по алгоритму Делоне [5]. Дифракционные классы исследованных кристаллов определены по систематике погасаний на развертках слоевых линий, снятых в камере КФОР (Сu-излучение). Пространственная группа симметрии для (1) (P2 $\left.2_{1} 2_{1}\right)$ определяется однозначно, для (2). определенному дифракционному классу соответствуют две пространственные группы $(A 2 / a$ и $A a)$, обе допустимые теорией плотной упаковки молекулярных кристаллов [ $\left.{ }^{4}\right]$. Плотность кристаллов измерена методом гидростатического взвешивания в смеси тетрахлорметана и гептана.

Значительные различия в химической и структурной формулах (1) и (2) не позволяли ожидать, что кристаллы этих веществ будут иметь изоморфные структуры. Приведенные в этом сообщении рентгеногра- 
фические данные подтверждают отсутствие изоструктурности исследованных соединений. В настоящее время ведется расшифровка кристаллической структуры (1).

\section{ЛИТЕ Р А Т Р А}

1. Кристьянсон П. Г., Арро 3. В., Суурпере А. О. Исследование реакции резорцинов с $\mathrm{N}$-оксиметил-в-капролактамом в присутствии кислоты. - $\mathrm{Tp}$. Таллинск. политехн. ин-та, 1978, № 459, с. $7-17$.

2. О я Х. П., К и и тьян сон П. Г., В ял и м е Т. К. Спектроскопическое исследование структуры $\mathrm{N}, \mathrm{N}^{\prime}-[(1,3-$-диоксифенил) -4,6-диметил]-ди- $\varepsilon$-капролактама. Тр. Таллинск. политехн. ин-та, 1980, № 491, с. $13-22$.

3. Оя Х. П., Липпма а Х. В., Кристьянсон П. Г., Пехк Т. И. Спектроскопическое исследование структуры $\mathrm{N}, \mathrm{N}^{\prime}, \mathrm{N}^{\prime \prime}-1(1,3-$-диоксифенил)-2,4,6-триметил]три-в-капролактама. - Тр. Таллинск. политехн. ин-та, 1978, № 459, с. 19-28.

4. К и т а й го род с к и й А. И. Молекулярные кристаллы. М., 1972.

5. Делоне Б., Падуров Н., Александров А. Математические основы структурного анализа кристаллов. Л., М., 1934.

Таллинский политехнический институт

Институт элементоорганических соединений Академии наук СССР

Поступила в редакцию $177 / \mathrm{X} \quad 1980$ 